\title{
Applicability of soil column incubation experiments to measure $\mathrm{CO}_{2}$ efflux**
}

\author{
Linlin Guo ${ }^{1,2 *}$, Taku Nishimura ${ }^{3}$, Hiromi Imoto ${ }^{3}$, and Zhigang Sun ${ }^{1,2 *}$ \\ ${ }^{1}$ Key Laboratory of Ecosystem Network Observation and Modeling, Institute of Geographic Sciences and Natural Resources \\ Research, Chinese Academy of Sciences, 11A Datun Road, Chaoyang District, Beijing, China 100101 \\ ${ }^{2}$ Yucheng Comprehensive Experimental Station, Institute of Geographic Sciences and Natural Resources Research, \\ Chinese Academy of Sciences, 11A Datun Road, Chaoyang District, Beijing, China 100101 \\ ${ }^{3}$ Graduate School of Agricultural and Life Sciences, The University of Tokyo, 1-1-1 Yayoi, Bunkyo District, Tokyo, Japan 113-0032
}

Received June 29, 2015; accepted October 14, 2015

A b s t r a c t. Accurate measurements of $\mathrm{CO}_{2}$ efflux from soils are essential to understand dynamic changes in soil carbon storage. Column incubation experiments are commonly used to study soil water and solute transport; however, the use of column incubation experiments to study soil $\mathrm{CO}_{2}$ efflux has seldom been reported. In this study, a 150-day greenhouse experiment with two treatments (no-tillage and tillage soils) was conducted to evaluate the applicability of soil column incubation experiments to study $\mathrm{CO}_{2}$ efflux. Both the chamber measurement and the gradient method were used, and results from the two methods were consistent: tillage increased soil cumulative $\mathrm{CO}_{2}$ efflux during the incubation period. Compared with fieldwork, incubation experiments can create or precisely control experimental conditions and thus have advantages for investigating the influence of climate factors or human activities on $\mathrm{CO}_{2}$ efflux. They are superior to bottle incubation because soil column experiments maintain a soil structure that is almost the same as that in the field, and thus can facilitate analyses on $\mathrm{CO}_{2}$ behaviour in the soil profile and more accurate evaluations of $\mathrm{CO}_{2}$ efflux. Although some improvements are still required for column incubation experiments, wider application of this method to study soil $\mathrm{CO}_{2}$ behaviour is expected.

$\mathrm{K}$ e y w o r d s: column incubation experiment, $\mathrm{CO}_{2}$ efflux, tillage, chamber method, gradient method

\section{INTRODUCTION}

Global warming caused by an increase in atmospheric greenhouse gas (GHG) concentrations, such as $\mathrm{CO}_{2}, \mathrm{~N}_{2} \mathrm{O}$, and $\mathrm{CH}_{4}$ threatens sustainable development. Soils can function as either a source or a sink for atmospheric $\mathrm{GHG}$ depending on land use and soil management. Appropriate

\footnotetext{
*Corresponding author e-mail: sun.zhigang@igsnrr.ac.cn guoll@igsnrr.ac.cn

**This research was supported by the 100 Talents Program of the Chinese Academy of Sciences and by Institute for Sustainable Agro-ecosystem Services (ISAS), University of Tokyo, for soil sampling, 2012-2014.
}

agricultural management enables increasing carbon storage and decreasing $\mathrm{CO}_{2}$ emissions (Lal, 2010; Luo et al., 2010). Accurate quantitation of $\mathrm{CO}_{2}$ efflux from soils is essential to assess dynamic changes in soil carbon storage.

Field monitoring using the chamber method is often employed to evaluate $\mathrm{CO}_{2}$ efflux from soils (Ahmad et al., 2009; Morell et al., 2011). However, field monitoring is laborious and time-consuming. Field monitoring is easily affected by environmental conditions, and the required experimental conditions are difficult to create or control. Therefore, laboratory incubation experiments have been carried out to evaluate soil $\mathrm{CO}_{2}$ production under different agricultural conditions. Plante and McGill (2002) incubated soils with differing simulated tillage frequencies in the laboratory to study the dynamics of soil organic matter. Dong et al. (2014) controlled water content and carbonate concentration in the soil to investigate the effects of moisture and carbonate addition on $\mathrm{CO}_{2}$ emission during closed-jar incubation.

Most of these experiments incubate a small amount of disturbed soil in closed bottles. The structure of the incubated soil is altered and different from that in the field; however, many previous studies have suggested that soil structure has a considerable effect on soil carbon dynamics (Conant et al., 2007; Six and Paustian, 2014). Column incubation experiments, using undisturbed soil sampled from the field, can maintain soil structure and evaluate the effects of changes in soil structure on soil $\mathrm{CO}_{2}$ efflux.

Additionally, bottle incubation experiments neglect the contributions of gas diffusion, which is the main mechanism of $\mathrm{CO}_{2}$ transport in the soil, to $\mathrm{CO}_{2}$ efflux. Assuming

(C) 2015 Institute of Agrophysics, Polish Academy of Sciences 
that molecular diffusion is predominantly responsible for gas transport in the soil, the gradient method based on Fick's law can be used to estimate $\mathrm{CO}_{2}$ efflux from the soil. Although the chamber method is commonly used for measuring $\mathrm{CO}_{2}$ efflux from the soil surface, there are several difficulties with this method. Precise measurement of $\mathrm{CO}_{2}$ efflux is difficult with the chamber method during rainfall or windy days because the environments are different within and outside the chamber (Maier and Schack-Kirchner, 2014; Wolf et al., 2011). Disturbance of the concentration gradient between soil and the atmosphere caused by covering the chamber may also increase experimental error in this method (Kutzbach et al., 2007). Thus, the gradient method has been used as an alternative or supplemental method to estimate soil $\mathrm{CO}_{2}$ efflux. Jassal et al. (2005) and Tang et al. (2003) estimated the $\mathrm{CO}_{2}$ efflux with Fick law and suggested the estimated data agreed well with the measured ones. Considering the advantages of monitoring soil properties in the profile, estimation of $\mathrm{CO}_{2}$ efflux with the gradient method can be carried out with column incubation experiments. However, existing studies commonly used soil column incubation to solve problems of water and solute transport in soils, and only a few studies evaluated $\mathrm{CO}_{2}$ efflux using soil column incubation. For example, Rottmann and Joergensen (2011) compared four methods of measuring $\mathrm{CO}_{2}$ production using the column incubation method, considering that this method could accurately regulate environmental conditions. Additionally, Camarda et al. (2009) used this method to investigate the effects of soil gas permeability and recirculation flux on soil $\mathrm{CO}_{2}$ efflux, considering that this experiment system could maintain soil structure and was available commercially. Volcanic ash soil is an important resource for agriculture in various regions of the world because of its unique chemical and physical properties, especially its high organic carbon content (Prado et al., 2007; Shoji et al., 1993). Because volcanic ash soil is an important carbon pool, it possesses a major challenge to mitigating emission of $\mathrm{CO}_{2}$ in the soil during agricultural activities. Optimum agricultural activities are considered to have the potential to restrict $\mathrm{CO}_{2}$ emissions from soil by changing soil properties (Gregorich et al., 2005; Tenesaca and Al-Kaisi, 2015). No-tillage farming has been known to improve soil structure, reduce soil erosion, and conserve soil moisture (Gupta and Sayre, 2007; Zuber et al., 2015). Recently, no-tillage farming has received much attention because many studies have shown that it contributes to the reduction of $\mathrm{CO}_{2}$ efflux from agricultural fields (AlvaroFuentes et al., 2007; Jabro et al., 2008). Finding ways to decrease soil $\mathrm{CO}_{2}$ efflux from agricultural soil requires accurate measurements of $\mathrm{CO}_{2}$ efflux.

The present study attempted to use column incubation experiments to investigate the $\mathrm{CO}_{2}$ efflux from an Andisol under two treatments (no-tillage and tillage) and to test the applicability of column incubation experiments. Measurements of the soil $\mathrm{CO}_{2}$ efflux with both the chamber method and the gradient method were conducted during the column incubation experiments.

\section{MATERIALS AND METHODS}

The soil was sampled at the experimental farm of the University of Tokyo located in Nishitokyo $\left(139^{\circ} 54^{\prime} \mathrm{E}\right.$, $\left.35^{\circ} 73^{\prime} \mathrm{N}\right)$, Tokyo, Japan. The area has a subtropical monsoon climate with an average annual air temperature of $16.5^{\circ} \mathrm{C}$, average rainfall of $1500 \mathrm{~mm}$, daily solar radiation of $10 \mathrm{MJ} \mathrm{m}^{-2}$, and relative humidity of $60 \%$. The soil is an Andisol derived from volcanic ash. Some of the soil physical properties are shown in Table 1. The sampling site used as an upland field was fallow for two years and covered by approximately $10 \mathrm{~cm}$ tall weeds. Prior to sampling, the weeds were removed, and $0.74 \mathrm{~kg} \mathrm{~m}^{-2}$ of leaf compost (with a total carbon content of $340.3 \mathrm{~g} \mathrm{~kg}^{-1}$ ) that is similar to the usual application rate of organic carbon in this region was applied to the soil.

T a b l e 1. Soil characteristics of the sampling site

\begin{tabular}{cccccc}
\hline Depth $(\mathrm{cm})$ & $\begin{array}{c}\text { Bulk density } \\
\left(\mathrm{Mg} \mathrm{m}^{-3}\right)\end{array}$ & $\begin{array}{c}\text { Saturated hydraulic } \\
\text { conductivity }\left(\mathrm{m} \mathrm{s}^{-1}\right)\end{array}$ & $\begin{array}{c}\text { Particle size } \\
\text { distribution* }(\%)\end{array}$ & $\begin{array}{c}\text { Particle density* } \\
\left(\mathrm{Mg} \mathrm{m}^{-3}\right)\end{array}$ & $\begin{array}{c}\text { Total carbon } \\
\left(\mathrm{g} \mathrm{kg}^{-1}\right)\end{array}$ \\
\hline $0-5$ & 0.90 & $3.510^{-7}$ & sand 40.5 & & 55.9 \\
$5-10$ & 0.86 & $1.010^{-6}$ & silt 37.9 & 2.57 & 54.5 \\
$10-15$ & 0.90 & $2.010^{-6}$ & clay 21.6 & & 55.7 \\
$15-25$ & 0.82 & $1.110^{-5}$ & sand 44.9 & & 55.5 \\
$25-35$ & 0.80 & $1.210^{-5}$ & silt 39.4 & 2.55 & 54.6 \\
& & clay 15.7 & & \\
\hline
\end{tabular}

*Soil particle size and density were measured at depths of 2.5 and $17.5 \mathrm{~cm}$. 
The experiments consisted of two treatments: no-tillage (NT) and tillage (T). For the T treatment, surface soil was tilled with a hoe to a depth of about $15 \mathrm{~cm}$ in the plot after compost application, and then slightly compacted. The tillage operation was conducted in one day. Undisturbed soil columns $(15 \mathrm{~cm}$ in diameter; $40 \mathrm{~cm}$ high) were acquired by driving $50 \mathrm{~cm}$ long polyvinyl chloride (PVC) cylinders (inner diameter, $15 \mathrm{~cm}$; sidewall thickness, $3 \mathrm{~mm}$ ) into the soil and carefully extracting the soil. A thin metal ring with a cutting edge was attached to the bottom of the PVC cylinder to prevent damage to the soil column during insertion. Because a $40 \mathrm{~cm}$ soil column was sampled, $10 \mathrm{~cm}$ of headspace was left in the PVC cylinder.

During the incubation period, copper-constantan thermocouples (Fig. 1A) were inserted into the soil $3 \mathrm{~cm}$ from the sidewall to monitor the soil temperature. Soil water pressure was monitored using porous cups (Fig. 1B) that were connected with pressure transducers. Thermocouples and porous cups were installed horizontally at depths of $2.5,12.5$, and $30.0 \mathrm{~cm}$ of the soil column. A data logger stored temperature and water pressure data at $10 \mathrm{~min}$ intervals (CR10X, Campbell Scientific Inc., Logan, UT). A gas sampling port (Fig. 1C) used for $\mathrm{CO}_{2}$ sampling was inserted at a depth of $2.5 \mathrm{~cm}$. The gas sampling port was a $7 \mathrm{~cm}$-long porous resin tube that was permeable to gas but not soil and water.

Soil columns were incubated in the glass greenhouse built on the top floor of the Life Science Research Building at the University of Tokyo. The incubation duration was 150 days (August 18 - January 14). Sunshine was the major source of light, and lamps were placed in the greenhouse for supplementary lighting on cloudy days. The temperature in the room was set to $30^{\circ} \mathrm{C}$ during the day $(06: 00-18: 00)$ and

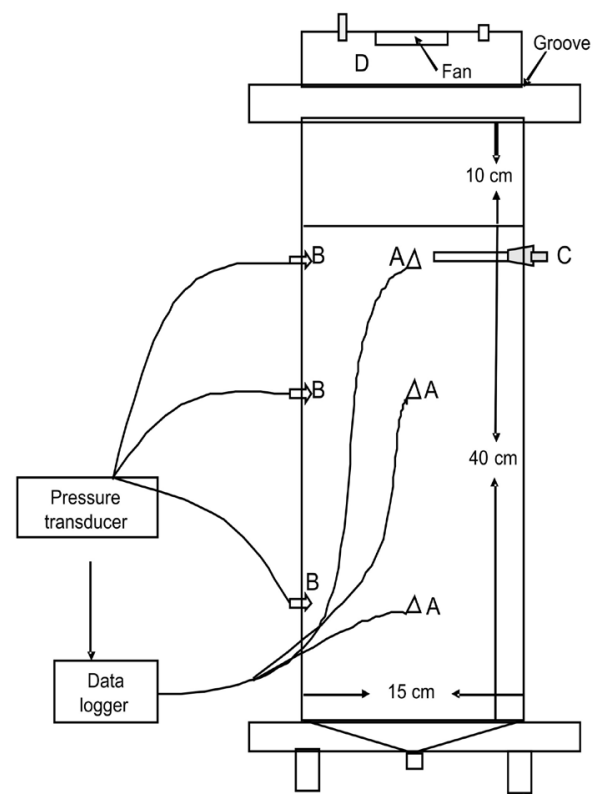

Fig. 1. Schematic of the experimental setup: A - thermocouples, $\mathrm{B}$ - porous cups, $\mathrm{C}$ - gas sampling port, and $\mathrm{D}$ - the chamber. $25^{\circ} \mathrm{C}$ during the night (18:00-06:00). During incubation, the soil surface was irrigated with $13.8 \mathrm{~mm}$ of water every $5 \mathrm{~d}$ to maintain soil moisture. This was equal to the amount of water evaporation in the greenhouse, and thus, soil water content was controlled to fluctuate within a certain range.

During the incubation period, $\mathrm{CO}_{2}$ efflux and concentration were measured at 7 day intervals. An acrylic cylindrical chamber (inner diameter $16.3 \mathrm{~cm}$; height $5.5 \mathrm{~cm}$ ) was fixed to the groove on the top of the PVC cylinder (Fig. 1D) to measure the $\mathrm{CO}_{2}$ efflux. The perimeter of the chamber was sealed with water to prevent gas leakage during measurement, and a circulating fan in the top of the chamber was used to mix the headspace air homogeneously. The gas inside the chamber was sampled using a $5 \mathrm{ml}$ plastic syringe at $0,10,20$, and $30 \mathrm{~min}$ after the chamber was closed. Gas samples were stored in $5 \mathrm{ml}$ vacuum glass vials and then brought back to the laboratory for quantification with a gas chromatograph (GC 2014, Shimadzu Inc., Tokyo). The $\mathrm{CO}_{2}$ efflux was calculated using the following equation:

$$
F=\rho\left(\frac{273}{T}\right)\left(\frac{V}{A}\right)\left(\frac{\Delta C}{\Delta t}\right)
$$

where: $F$ is the $\mathrm{CO}_{2}$ efflux $\left(\mathrm{g} \mathrm{CO}_{2}-\mathrm{C} \mathrm{m}^{-2} \mathrm{~d}^{-1}\right), \rho$ is the gas density $\left(\mathrm{g} \mathrm{m}^{-3}\right), T$ is the temperature $(\mathrm{K}), V$ is the volume of the chamber $\left(\mathrm{m}^{3}\right), A$ is the area of the soil column surface $\left(\mathrm{m}^{2}\right)$, $\Delta C$ is the concentration increment $\left(\mathrm{m}^{3} \mathrm{~m}^{-3}\right)$, and $\Delta t$ is the time interval (in days).

After $\mathrm{CO}_{2}$ efflux measurement, the soil $\mathrm{CO}_{2}$ concentration at a depth of $2.5 \mathrm{~cm}$ was determined by sampling the soil gas through the gas sampling port and quantifying it by gas chromatography. The $\mathrm{CO}_{2}$ concentration in the atmosphere was determined by sampling the air near the soil surface with a syringe and quantifying it by gas chromatography.

After incubation, the soil columns were split, and the soil properties of each layer were measured. Water retention curves were determined by the hanging water method $(-10 \mathrm{~cm}>$ soil water potential $>-100 \mathrm{~cm})$ and the pressure plate method $(-100 \mathrm{~cm}>$ soil water potential $>-1000 \mathrm{~cm})$ (Klute, 1986). Soil volumetric water content was calculated from the water retention curves and soil water potentials. Dry bulk density was determined gravimetrically by using $100 \mathrm{~cm}^{3}$ undisturbed soil cores (Blake and Hartge, 1986a). Soil particle density was determined by the pycnometer method (Blake and Hartge, 1986b). Soil total porosity was computed from the data on dry bulk density and particle density. The difference between the total porosity and volumetric water content was assumed to be the air-filled porosity of the soil.

Soil gas diffusivity was measured using $100 \mathrm{~cm}^{3}$ soil cores at five water potentials $(-20,-63,-200,-500$, and $-1000 \mathrm{~cm}$ ). Prior to measurement, the water potentials of the soil cores were adjusted to a certain value using the pressure-plate chamber. The diffusion chamber, with $\mathrm{O}_{2}$ as the tracer gas, was used for the measurement of soil gas 
diffusivity (Hamamoto et al., 2011). The upper end of the soil core was exposed to the atmosphere, and the bottom was connected with the diffusion chamber. The diffusion chamber was flushed using pure $\mathrm{N}_{2}$ gas before measurement. The $\mathrm{O}_{2}$ inside the diffusion chamber was measured by a galvanic electrode (Oxygen Sensor Ke12, GS Yuasa Co., Kyoto) connected to a data logger. The soil gas diffusivity was calculated by assessing the changes in the $\mathrm{O}_{2}$ concentration in the chamber using the following equation (Currie, 1960):

$$
\frac{C\left(L_{s}, t\right)-C_{i}}{C_{0}-C_{i}}=\frac{2 h \exp \left(-D_{p} a_{1}^{2} t / \varepsilon\right)}{L_{s}\left(a_{1}^{2}+h^{2}\right)+h},
$$

where: $D_{p}$ is the gas diffusion coefficient in the soil $\left(\mathrm{m}^{2} \mathrm{~s}^{-1}\right)$, $C\left(L_{s}, t\right)$ is the $\mathrm{O}_{2}$ concentration in the diffusion chamber $\left(\mathrm{g} \mathrm{m}^{-3}\right), C_{i}$ is the $\mathrm{O}_{2}$ concentration in the atmosphere $\left(\mathrm{g} \mathrm{m}^{-3}\right)$, $C_{0}$ is the $\mathrm{O}_{2}$ concentration at $t=0\left(\mathrm{~g} \mathrm{~m}^{-3}\right), \varepsilon$ is the air-filled porosity $\left(\mathrm{m}^{3} \mathrm{~m}^{-3}\right), L_{s}$ is the height of the soil core $(\mathrm{m}), a_{1}$ is the first positive square root of $h L_{s}=a L_{s} \tan \left(a L_{s}\right)$, and $h=\varepsilon / L_{a}\left(L_{a}\right.$ is the height of the diffusion chamber, $\left.\mathrm{m}\right)$. Three replicates were conducted in this experiment.

The least significant difference method (LSD) was used to determine any significant differences between treatments. Non-linear regression analysis was used to model the soil gas diffusivity as a function of air-filled porosity. The relationship between the estimated and measured $\mathrm{CO}_{2}$ efflux was analysed using Pearson correlation analysis. All statistical analyses were performed using SPSS software procedures (IBM SPSS statistics 20.0).

\section{RESULTS AND DISCUSSION}

The column incubation experiments maintained a soil structure comparable to that in the field experiments, and $\mathrm{CO}_{2}$ effluxes under the NT and T treatments were investigated with the chamber method. The difference in soil $\mathrm{CO}_{2}$ efflux between the NT $\left(2.39 \mathrm{~g} \mathrm{~m}^{-2} \mathrm{~d}^{-1}\right)$ and $\mathrm{T}(4.48 \mathrm{~g}$ $\mathrm{m}^{-2} \mathrm{~d}^{-1}$ ) treatments on the first day (August 18) was notable $(p<0.05, n=3)$. In this experiment, the tillage operation was conducted 1 day before the first measurement of the $\mathrm{CO}_{2}$ efflux. Tillage disturbed the soil and accelerated the gas exchange between the soil air phase and the atmosphere. The $\mathrm{CO}_{2}$ stored in the air-filled pores of the soil was quickly released into the atmosphere over the first several days. As a consequence, the $\mathrm{CO}_{2}$ efflux under the $\mathrm{T}$ treatment was obviously higher than that under the NT treatment on the first day. Kessavalou et al. (1998) and Reicosky and Archer (2007) reported results similar to those of the present study. No noticeable increase or decrease in the $\mathrm{CO}_{2}$ efflux was observed after the first day of the incubation period (August 19 - January 14) (Fig. 2). The soil $\mathrm{CO}_{2}$ efflux under the $\mathrm{T}$ treatment fluctuated in the range of $0.2-$ $1.1 \mathrm{~g} \mathrm{~m}^{-2} \mathrm{~d}^{-1}$, which was similar to that in the NT treatment (0.0-1.0 $\left.\mathrm{g} \mathrm{m}^{-2} \mathrm{~d}^{-1}\right)$. Soil cumulative $\mathrm{CO}_{2}$ efflux under the

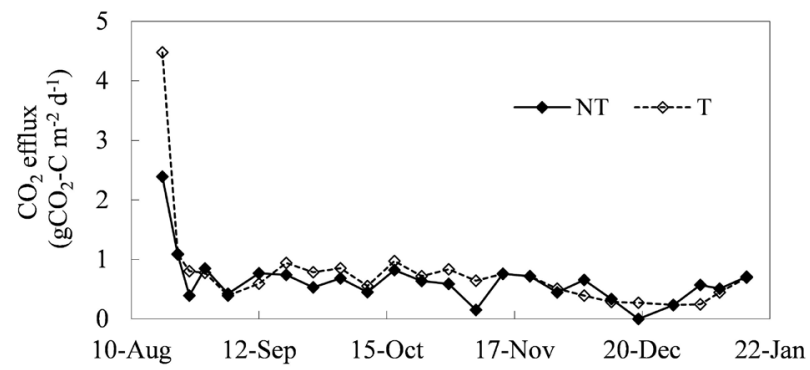

Fig. 2. Soil $\mathrm{CO}_{2}$ effluxes under the no-tillage (NT) and tillage (T) treatments during the incubation period.

$\mathrm{T}$ treatment $\left(95.67 \mathrm{~g} \mathrm{~m}^{-2}\right)$ for the 150 days of incubation was higher than that under the NT treatment $\left(84.97 \mathrm{~g} \mathrm{~m}^{-2}\right)$ $(\mathrm{p}<0.05, \mathrm{n}=3)$.

Selected results of the temporal changes in soil tempe rature and volumetric water content that could be controlled by column incubation are shown in Fig. 3. Soil temperatures at depths of $2.5,12.5$, and $30 \mathrm{~cm}$ under the two treatments fluctuated with the greenhouse temperature and ranged between 25 and $30^{\circ} \mathrm{C}$ (Fig. 3a, 3b). Moreover, the range of fluctuation of soil temperature under the NT treatment was slightly larger than that under the $\mathrm{T}$ treatment. Soil disturbance caused by tillage leads to a greater air phase and fewer particles, which in turn depress soil thermal conductivity. Changes in soil thermal conductivity contribute to the differences in soil temperatures between the two treatments. After irrigation, volumetric water contents of the surface soils $(2.5 \mathrm{~cm})$ under the two treatments rapidly increased and then decreased gradually as a result of evaporation and redistribution (Fig. 3c, 3d). Upon irrigation, water contents at depths of $12.5 \mathrm{~cm}$ and $30 \mathrm{~cm}$ also increased but to a lesser extent and then decreased. Soil water content fluctuated within a certain range because of supplemental irrigation during incubation, and similar soil water content was observed at a depth of $30 \mathrm{~cm}$ in both treatments. However, the $\mathrm{T}$ treatment resulted in smaller volumetric water content at depths of 2.5 and $12.5 \mathrm{~cm}$ as compared with the NT treatment. Tillage loosened the soil of the plough layer, and this led to a reduction in bulk density and a rise in total porosity of the plough layer (Table 2). Since tillage increased soil unsaturated hydraulic conductivity (Kargas and Londra, 2015; Miller et al., 1998), lower soil volumetric water content was observed under the T treatment. Corresponding to lower volumetric water content of shallow soils, tillage increased the soil air-filled porosity at depths of $2.5 \mathrm{~cm}$ and $12.5 \mathrm{~cm}$ (Fig. 3e, 3f). Therefore, during the incubation period, soil aeration resulting from the air-filled porosity would be higher under the $\mathrm{T}$ treatment than that under the NT treatment. High aeration because of tillage increased the $\mathrm{O}_{2}$ level in the soil, which accelerated microbial respiration (Gomez and Garland, 2012; Silva et al., 2011), and thus might contribute to the higher cumulative $\mathrm{CO}_{2}$ efflux from the tilled soil. 
a

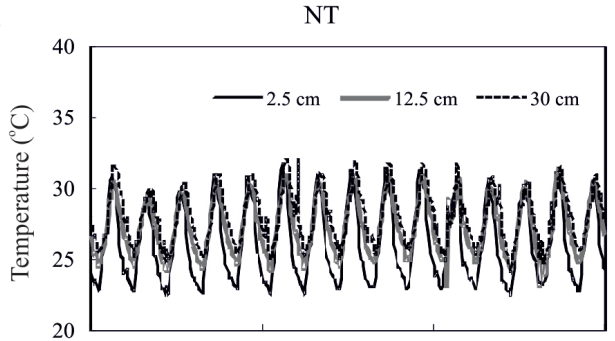

$\mathrm{c}$

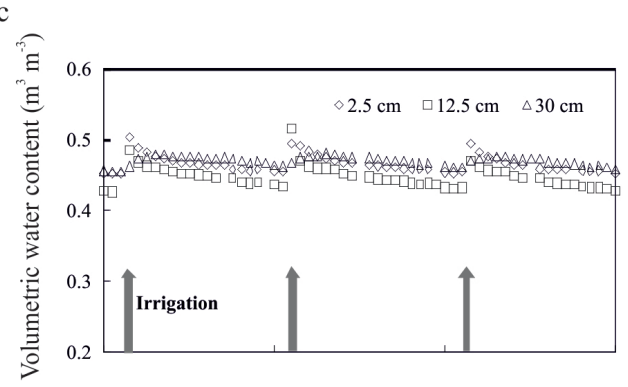

$\mathrm{e}$

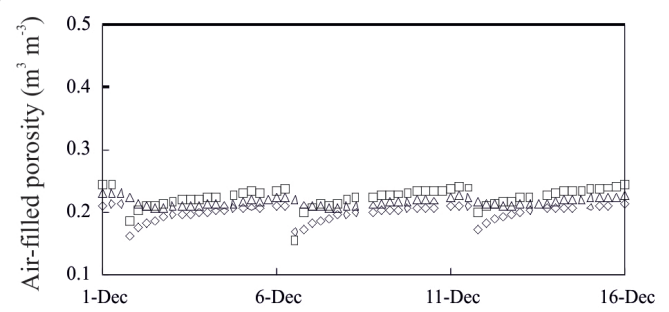

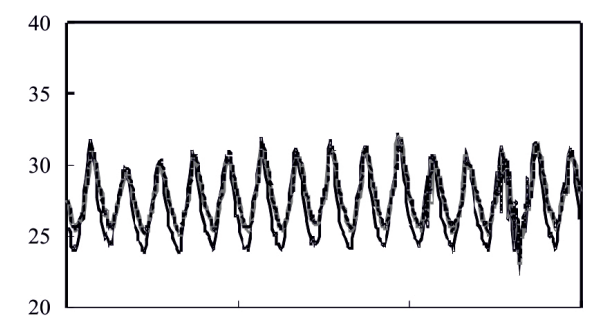

d

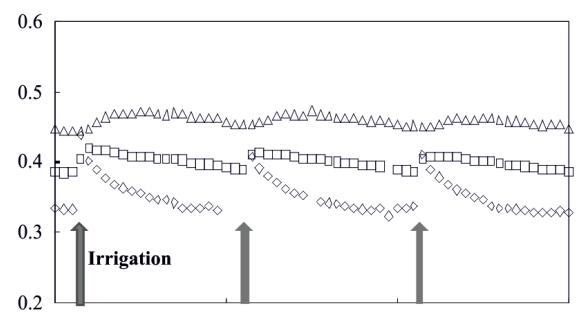

f

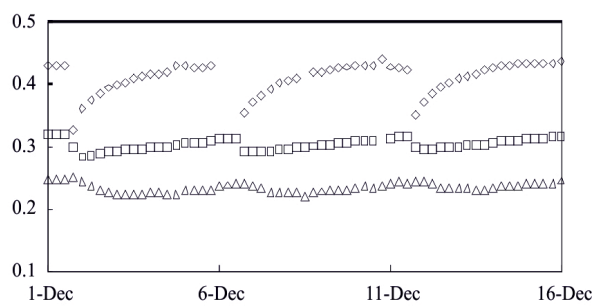

Fig. 3. Soil temperatures, volumetric water contents, and air-filled porosities at depths of 2.5, 12.5, and $30 \mathrm{~cm}$ under no-tillage (NT) and tillage $(\mathrm{T})$ treatments (15 day); temperatures in: $\mathrm{a}-\mathrm{NT}, \mathrm{b}-\mathrm{T}$; volumetric water contents in: $\mathrm{c}-\mathrm{NT}$, d-T; air-filled porosities in: e $-\mathrm{NT}, \mathrm{f}-\mathrm{T}$.

T a b l e 2. Soil bulk density and total porosity under the notillage (NT) and tillage (T) treatments

\begin{tabular}{cccccc}
\hline \multirow{2}{*}{$\begin{array}{c}\text { Depth } \\
(\mathrm{cm})\end{array}$} & \multicolumn{2}{c}{ Bulk density $\left(\mathrm{g} \mathrm{cm}^{-3}\right)$} & & \multicolumn{2}{c}{ Total porosity $\left(\mathrm{m}^{3} \mathrm{~m}^{-3}\right)$} \\
\cline { 2 - 3 } \cline { 5 - 6 } 2.5 & $\mathrm{NT}$ & $\mathrm{T}$ & & $\mathrm{NT}$ & $\mathrm{T}$ \\
\hline 7.5 & $0.85 \mathrm{a}$ & $0.64 \mathrm{~b}$ & & $0.67 \mathrm{a}$ & $0.75 \mathrm{~b}$ \\
12.5 & $0.83 \mathrm{a}$ & $0.76 \mathrm{~b}$ & & $0.66 \mathrm{a}$ & $0.76 \mathrm{~b}$ \\
20 & $0.81 \mathrm{a}$ & $0.78 \mathrm{a}$ & & $0.68 \mathrm{a}$ & $0.71 \mathrm{~b}$ \\
30 & $0.81 \mathrm{a}$ & $0.79 \mathrm{a}$ & & $0.68 \mathrm{a}$ & $0.69 \mathrm{a}$ \\
\hline
\end{tabular}

Significant differences between treatments are indicated with different letters $(\mathrm{p}<0.05, \mathrm{n}=3)$.

Gas diffusion is the main mechanism of gas transport within and between soils and the atmosphere, and hence the gradient method based on Fick law (Eq. (3)) has been proposed to estimate soil $\mathrm{CO}_{2}$ efflux from the soil surface. Accordingly, based on the gas diffusivity and soil $\mathrm{CO}_{2}$ concentration gradient $(0-2.5 \mathrm{~cm})$ data obtained from the column incubation experiment, we used Eq. (3) to estimate $\mathrm{CO}_{2}$ efflux:

$$
F=-D_{P} \frac{\Delta C^{\prime}}{\Delta z}
$$

where: $F$ is the gas flux from the soil $\left(\mathrm{g} \mathrm{CO}_{2}-\mathrm{C} \mathrm{m}^{-2} \mathrm{~d}^{-1}\right), D_{p}$ is the gas diffusion coefficient in the soil $\left(\mathrm{m}^{2} \mathrm{~d}^{-1}\right), \Delta C$ is the soil $\mathrm{CO}_{2}$ concentration gradient $\left(\mathrm{g} \mathrm{m}^{-3}\right)$, and $\Delta z$ is the thickness of the soil layer $(\mathrm{m})$.

Because continuous measurement of gas diffusivities is difficult, predictive models developed by fitting curves were used to estimate soil gas diffusivities (Moldrup et al., 2000; Deepagoda et al., 2011). As shown in Fig. 4, an exponential relationship was observed between soil air-filled porosity and gas diffusivity; hence, soil gas diffusivity could be described as a function of the air-filled porosity. However, the range of air-filled porosities at water potentials of -20 to $-1000 \mathrm{~cm} \mathrm{H}_{2} \mathrm{O}$ under the $\mathrm{T}$ treatment was lower than that under the NT treatment; this difference may be attributed to changes in soil structure and, thus, water retention curves due to tillage. Based on the measured gas diffusivities at five specific water potentials $(-20,-63,-200$, -500 , and $-1000 \mathrm{~cm} \mathrm{H}_{2} \mathrm{O}$ ), fitting curves were developed for both NT $\left(\mathrm{Y}=2.37 \mathrm{X}^{2.78}\right)$ and $\mathrm{T}\left(\mathrm{Y}=3.18 \mathrm{X}^{3.65}\right)$ treatments. Because water potentials in soils during the incubation period were monitored accurately in the column experiment, 
a

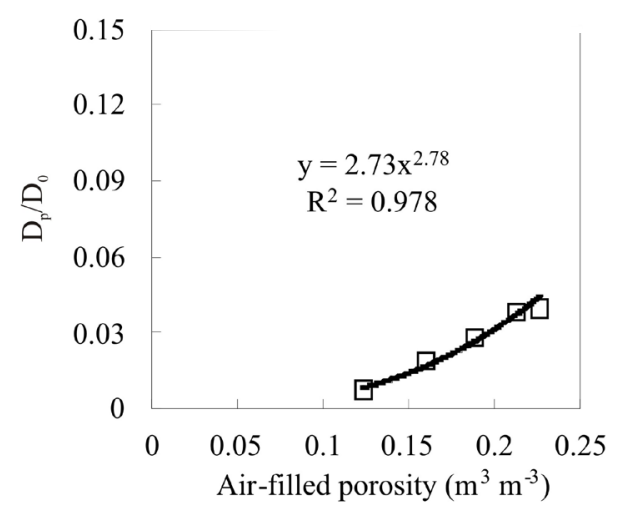

b

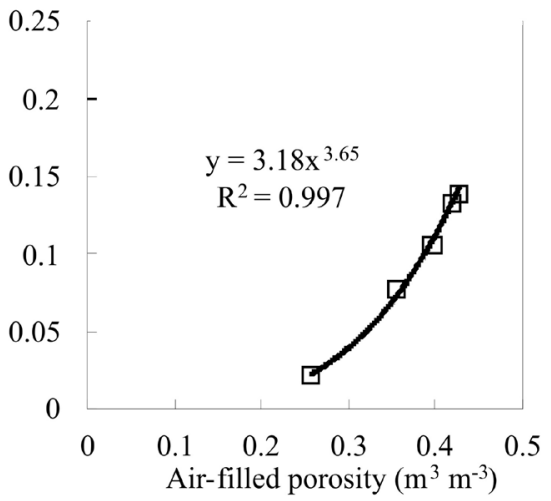

Fig. 4. Exponential relationships between soil gas diffusivities $\left(\mathrm{D}_{\mathrm{p}} / \mathrm{D}_{0}\right)$ and air-filled porosities for: $a-$ no-tillage $(N T)$ and $b-$ tillage (T) treatments. $\mathrm{D}_{\mathrm{p}}$ and $\mathrm{D}_{0}$ are the gas diffusion coefficient in the: soil and air $\left(\mathrm{m}^{2} \mathrm{~s}^{-1}\right)$, respectively.

a

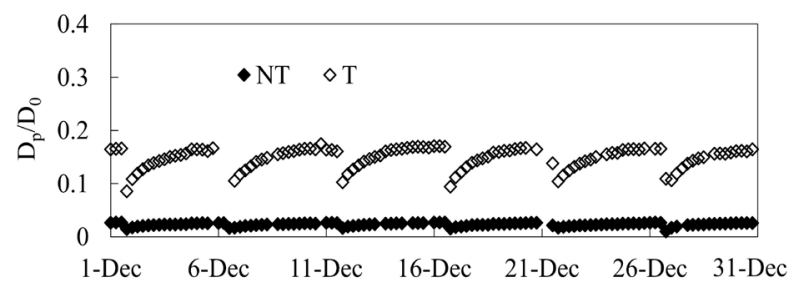

b

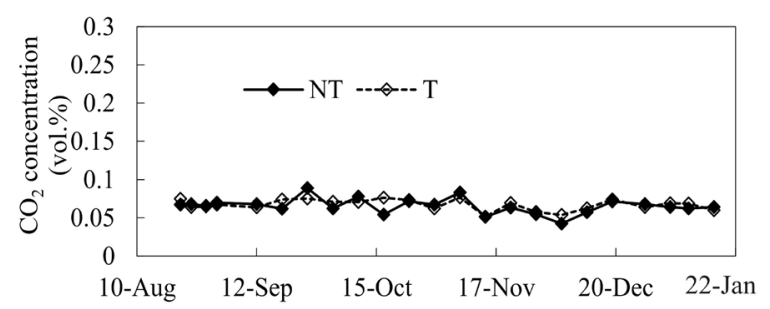

$\mathrm{c}$

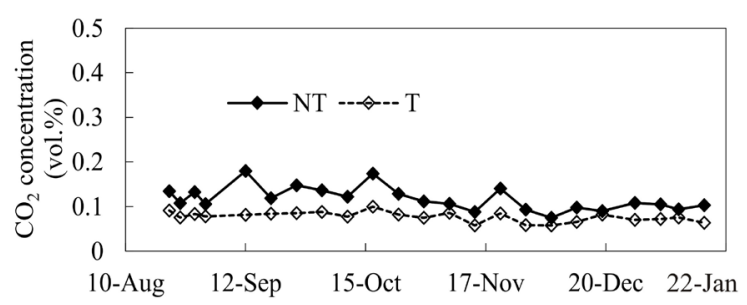

d

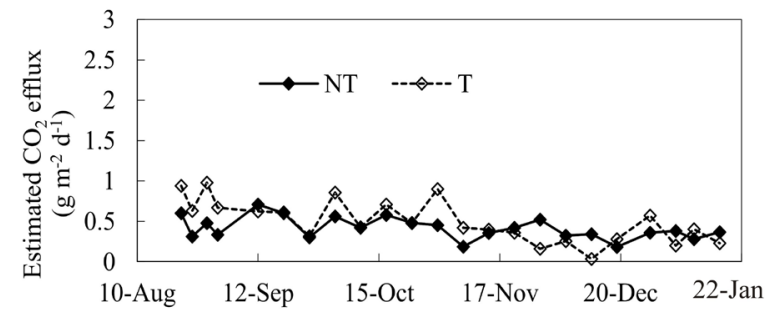

temporal changes in soil air-filled porosity in the two treatments were available. Therefore, soil gas diffusivities at depths of $0-5 \mathrm{~cm}$ could be predicted (Fig. 5a) with values of air-filled porosity and fitting curves.

The $\mathrm{CO}_{2}$ concentrations in the surface air and at a depth of $2.5 \mathrm{~cm}$ under the two treatments are shown in Fig. 5b, c. No clear difference in the $\mathrm{CO}_{2}$ concentration in the surface air was observed between the NT and T treatments. The soil $\mathrm{CO}_{2}$ concentration under the NT treatment at a depth of $2.5 \mathrm{~cm}$ was higher than that under the T treatment. Greater air-filled porosity and gas diffusivity of the tilled soil could be a cause of the lower soil $\mathrm{CO}_{2}$ concentration.

Similar to the measured results, distinct differences in the estimated $\mathrm{CO}_{2}$ efflux between the NT $\left(1.90 \mathrm{~g} \mathrm{~m}^{-2} \mathrm{~d}^{-1}\right)$ and $\mathrm{T}\left(4.91 \mathrm{~g} \mathrm{~m}^{-2} \mathrm{~d}^{-1}\right)$ treatments were observed on the first day of the incubation period. Except for the first day, no noticeable increase or decrease in the $\mathrm{CO}_{2}$ efflux was observed, as shown in Fig. 5d. The estimated cumulative $\mathrm{CO}_{2}$ efflux under the $\mathrm{T}$ treatment $\left(79.14 \mathrm{~g} \mathrm{~m}^{-2} \mathrm{~d}^{-1}\right)$ during the 150-day incubation period was higher than that under the NT treatment $\left(65.02 \mathrm{~g} \mathrm{~m}^{-2} \mathrm{~d}^{-1}\right)$. A linear relationship $(\mathrm{p}<0.05)$ was observed between the measured and estimated soil $\mathrm{CO}_{2}$ effluxes (Fig. 6). However, the estimated data showed a tendency to underestimate the soil $\mathrm{CO}_{2}$ effluxes, similar to results reported by Fierer et al. (2005) and Kusa et al. (2008). A source of a bias for the gradient method may come from an assumption that the $\mathrm{CO}_{2}$ flux at $0-2.5 \mathrm{~cm}$ in depth represents the $\mathrm{CO}_{2}$ efflux from the soil surface to the atmosphere. This assumption neglects soil $\mathrm{CO}_{2}$ production in the 0-2.5 cm - depth layer. However, the shallow soil layer could be active in $\mathrm{CO}_{2}$ production because the soil $\mathrm{O}_{2}$ level might be high due to quick gas exchange with the atmosphere. With compensation by using measured $\mathrm{CO}_{2}$ efflux, the gradient method used in the column incubation experiment could provide an acceptable estimation of $\mathrm{CO}_{2}$ efflux.

Fig. 5. Soil gas diffusivities at depths of 0-5 cm (a) (selected results of soil gas diffusivities are shown), soil $\mathrm{CO}_{2}$ concentrations in the surface air (b), $\mathrm{CO}_{2}$ concentrations at a depth of $2.5 \mathrm{~cm}$ (c), estimated $\mathrm{CO}_{2}$ effluxes (d) for the no-tillage (NT) and tillage (T) treatments (August 19 - January 14). 


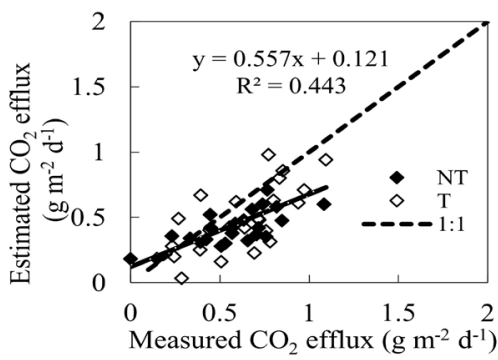

Fig. 6. Relationship between the measured and estimated soil $\mathrm{CO}_{2}$ effluxes.

The incubation experiment has advantages in observing the experimental process and saving labours. More importantly, compared with fieldwork, simulation or accurate control of environmental factors can be done in column incubation experiments. In the present study, moisture and temperature, important factors affecting soil respiration, were controlled within a relatively stable range, and thus the effects of tillage on soil $\mathrm{CO}_{2}$ efflux could be accurately estimated. Rather than temperature and moisture conditions, other experimental conditions (eg climate factors, agricultural managements, soil gas state) can be created or precisely controlled in column incubation experiments (Case et al., 2014; De Graaff et al., 2008). In the investigation of the influence of climate factors or human activity on $\mathrm{CO}_{2}$ release, incubation experiments are preferred if special or precise experimental conditions are required.

In the present study, changes in soil properties, particularly water content and air-filled porosity, were accurately observed during the incubation period. The observed results could help to understand higher $\mathrm{CO}_{2}$ production from tilled soil, which would be due to the increase in the air-filled porosity and gas diffusivity at the $0-15 \mathrm{~cm}$ depth caused by tillage. Additionally, the column incubation method can be used to monitor the gas concentration and thus to examine gas transport in soil. Based on the theory of gas diffusion, the gradient method could be conducted with column incubation experiments to estimate temporal changes in the soil $\mathrm{CO}_{2}$ efflux by using soil $\mathrm{CO}_{2}$ concentration and gas diffusivity. Unlike the chamber method, measurements of soil $\mathrm{CO}_{2}$ concentration and moisture conditions are not affected by climatic conditions. Therefore, this method can compensate for the shortcomings of chamber measurements and serve as an alternative or supplemental method for $\mathrm{CO}_{2}$ efflux evaluation. This type of analysis of $\mathrm{CO}_{2}$ production and transport in the soil profile cannot be achieved through bottle incubation.

Moreover, the structure of the undisturbed soil column used for this experiment was almost the same as that in the field, and thus the results were more accurate than those obtained in bottle incubation. Chu et al. (2007) reported values of 0.427-0.524 $\mathrm{g} \mathrm{CO}_{2}-\mathrm{C} \mathrm{m}^{-2} \mathrm{~d}^{-1} \mathrm{CO}_{2}$ efflux from an Andisol upland field in Japan under different types of fer- tilizer management using a closed chamber method that was the same as that used in the present study. Similarly, Nakadai et al. (2002) conducted a field experiment using a chamber method and reported that the average soil $\mathrm{CO}_{2}$ efflux from an Andisol under the tillage treatment was in the range of $0.73-1.39 \mathrm{~g} \mathrm{CO}_{2}-\mathrm{C} \mathrm{m}^{-2} \mathrm{~d}^{-1}$ according to the season. However, the values of $\mathrm{CO}_{2}$ efflux from Andisol determined from bottle incubation were significantly overestimated (Dumale et al., 2009; Nakadai et al., 2002), because the gas status and soil structure in bottle incubation were significantly different from those in the field experiment. The results of $\mathrm{CO}_{2}$ efflux from soils measured with the column incubation experiment were superior to those from bottle incubation experiments.

However, compared with the bottle incubation, preparing the soil column is complicated and costly. During the experiment, controlling the environmental conditions often requires special techniques or instruments. That may be the main reason that limited studies have been carried out with column incubation. Because column incubation has obvious advantages for analysis of $\mathrm{CO}_{2}$ behaviour in soils, further improvements in this method are expected.

\section{CONCLUSIONS}

1. To evaluate the applicability of soil column incubation experiments in studying $\mathrm{CO}_{2}$ effluxes, a 150-day column incubation experiment was conducted to measure $\mathrm{CO}_{2}$ efflux from no-tilled and tilled soils. Both the chamber measurement and the gradient method were used, and results from the two methods were consistent: tillage increased the cumulative $\mathrm{CO}_{2}$ efflux from the soil during the incubation period.

2. Compared with the fieldwork, incubation experiments allow creating or precisely controlling experimental conditions and thus have advantages in investigating the influence of climate factors or human activity on $\mathrm{CO}_{2}$ efflux. Superior to bottle incubation, soil column experiments can focus on analysis of the mechanism of $\mathrm{CO}_{2}$ behaviour in soil profiles and yield more accurate results. Considering the advantages of column incubation experiments, we expect them to be more widely employed in the analysis of $\mathrm{CO}_{2}$ behaviour in soils.

\section{REFERENCES}

Ahmad S., Li C., Dai G., Zhan M., Wang J., and Pan S., 2009. Greenhouse gas emission from direct seeding paddy field under different rice tillage systems in central China. Soil Till. Res., 106, 54-61.

Alvaro-Fuentes J., Cantero-Martinez C., Lopez M.V., and Arrue J.L., 2007. Soil carbon dioxide fluxes following tillage in semiarid Mediterranean agroecosystems. Soil Till. Res., 96, 331-341.

Blake G.R. and Hartge K.H., 1986a. Bulk density. Methods of soil analysis, Part 1. Am. Soc. Agron. Press, Madison, WI, USA. 
Blake G.R. and Hartge K.H., 1986b. Particle density. Methods of soil analysis, Part 1. Am. Soc. Agron. Press, Madison, WI, USA.

Camarda M., Gurrieri S., and Valenza M., 2009. Effects of soil gas permeability and recirculation flux on soil $\mathrm{CO}_{2}$ flux measurements performed using a closed dynamic accumulation chamber. Chem. Geol., 265, 387-393.

Case S.D.C., McNamara N.P., Reay D.S., and Whitaker J., 2014. Can biochar reduce soil greenhouse gas emissions from a Miscanthus bioenergy crop? Global Change Biology Bioenergy, 6, 76-89.

Chu H., Hosen Y., and Yagi K., 2007. $\mathrm{NO}, \mathrm{N}_{2} \mathrm{O}, \mathrm{CH}_{4}$ and fluxes in winter barley field of Japanese Andisol as affected by $\mathrm{N}$ fertilizer management. Soil Biol. Biochem., 39, 330-339.

Conant R.T., Easter M., Paustian K., Swan A., and Williams S., 2007. Impacts of periodic tillage on soil C stocks: A synthesis. Soil Till. Res., 95, 1-10.

Currie J.A., 1960. Gaseous diffusion in porous media: I. A nonsteady state method. Br. J. Appl. Phys., 11, 318-324.

De Graaff M.A., van Kessel C., and Six J., 2008. The impact of long-term elevated $\mathrm{CO}_{2}$ on $\mathrm{C}$ and $\mathrm{N}$ retention in stable $\mathrm{SOM}$ pools. Plant and Soil, 303, 311-321.

Deepagoda T.K.K.C., Moldrup P., Schjonning P., Wollesen de Jonge L., Kawamoto K., and Komatus T., 2011. Densitycorrected models for gas diffusivity and air permeability in unsaturated soil. Vadose Zone J., 10, 226-238.

Dong Y.J., Cai M., and Zhou J.B., 2014. Effects of moisture and carbonate additions on $\mathrm{CO}_{2}$ emission from calcareous soil during closed-jar incubation. J. Arid Land, 6, 37-43.

Dumale W.A., Miyazaki T., Nishimura T., and Seki K., 2009. $\mathrm{CO}_{2}$ evolution and short-term carbon turnover in stable soil organic carbon from soils applied with fresh organic matter. Geophysical Research Letters, 36, L01301.

Fierer N., Chadwick O.A., and Trumbore S.E., 2005. Production of $\mathrm{CO}_{2}$ in soil profiles of a California annual grassland. Ecosystems, 8, 412-429.

Gomez E. and Garland J.L., 2012. Effects of tillage and fertilization on physiological profiles of soil microbial communities. Appl. Soil Ecol., 61, 327-332.

Gregorich E.G., Rochette P., VandenBygaart A.J., and Angers D.A., 2005. Greenhouse gas contributions of agricultural soils and potential mitigation practices in Eastern Canada. Soil Till. Res., 83, 53-72.

Gupta R. and Sayre K., 2007. Conservation agriculture in South Asia. J. Agric. Sci., 145, 207-214.

Hamamoto S., Moldrup P., Kawamoto K., de Jonge L.W., Schjonning P., and Komatsu T., 2011. Two-region extended Archie's law model for soil air permeability and gas diffusivity. Soil Sci. Soc. Am. J., 75, 795-806.

Jabro J.D., Sainju U., Stevens W.B., and Evans R.G., 2008. Carbon dioxide flux as affected by tillage and irrigation in soil converted from perennial forages to annual crops. J. Environ. Manage., 88, 1478-1484.

Jassal R., Black A., Novak M., Morgenstern K., Nesic Z., and Gaumont-Guay D., 2005. Relationship between soil $\mathrm{CO}_{2}$ concentrations and forest-floor $\mathrm{CO}_{2}$ effluxes. Agric. For. Meteorol., 130, 176-192.
Kargas G. and Londra P.A., 2015. Effect of tillage practices on the hydraulic properties of a loamy soil. Desalin. Water Treat., 54, 2138-2146.

Kessavalou A., Doran J.W., Mosier A.R., and Drijber R.A., 1998. Greenhouse gas fluxes following tillage and wetting in a wheat-fallow cropping system. J. Environ. Qual., 27, 1105-1116.

Klute A., 1986. Water retention: laboratory methods. Methods of soil analysis, Part 1. Am. Soc. Agron. Press, Madison, WI, USA.

Kusa K., Sawamoto T., Hu R.G., and Hatano R., 2008. Comparison of the closed-chamber and gas concentration gradient methods for measurement of $\mathrm{CO}_{2}$ and $\mathrm{N}_{2} \mathrm{O}$ fluxes in two upland field soils. Soil Sci. Plant Nut., 54, 777-785.

Kutzbach L., Schneider J., Sachs T., Giebels M., Nykanen H., Shurpali N.J., and Wilmking M., 2007. $\mathrm{CO}_{2}$ flux determination by closed-chamber methods can be seriously biased by inappropriate application of linear regression. Biogeosciences, 4, 1005-1025.

Lal R., 2010. Managing soils and ecosystems for mitigating anthropogenic carbon emissions and advancing global food security. Bioscience, 60, 708-721.

Luo Z.K., Wang E.L., and Sun O.J., 2010. Soil carbon change and its responses to agricultural practices in Australian agro-ecosystems: A review and synthesis. Geoderma, 155, 211-223.

Maier M. and Schack-Kirchner H., 2014. Using the gradient method to determine soil gas flux: A review. Agric. For. Meteorol., 192, 78-95.

Miller J.J., Sweetland N.J., Larney F.J., and Volkmar K.M., 1998. Unsaturated hydraulic conductivity of conventional and conservation tillage soils in southern Alberta. Can. J. Soil Sci., 78, 643-648.

Moldrup P., Olesen T., Schjonning P., Yamaguchi T., and Rolston D.E., 2000. Predicting the gas diffusion coefficient in undisturbed soil from soil water characteristics. Soil Sci. Soc. Am. J., 64, 94-100.

Morell F.J., Cantero-Martinez C., Lampurlanes J., Plaza-Bonilla D., and Alvaro-Fuentes J., 2011. Soil carbon dioxide flux and organic carbon content: Effects of tillage and nitrogen fertilization. Soil Sci. Soc. Am. J., 75, 1874-1884.

Nakadai T., Yokozawa M., Ikeda H., and Koizumi H., 2002. Diurnal changes of carbon dioxide flux from bare soil in agricultural field in Japan. Appl. Soil Ecol., 19, 161-171.

Plante A.F. and McGill W.B., 2002. Soil aggregate dynamics and the retention of organic matter in laboratory-incubated soil with differing simulated tillage frequencies. Soil Till. Res., 66, 79-92.

Prado B., Duwig C., Hidalgo C., Gomez D., Yee H., Prat C., Esteves M., and Etchevers J., 2007. Characterization, functioning and classification of two volcanic soil profiles under different land uses in Central Mexico. Geoderma, 139, 300-313

Reicosky D.C. and Archer D.W., 2007. Moldboard plow tillage depth and short-term carbon dioxide release. Soil Till. Res., 94, 109-121. 
Rottmann N. and Joergensen R.G., 2011. Measuring the $\mathrm{CO}_{2}$ production from maize-straw-amended soil columnsa comparison of four methods. J. Plant Nutr. Soil Sc., 174, 373-380.

Shoji S., Nanzyo M., and Dahlgren R., 1993. Volcanic ash soils. Elsevier Science Press, Amsterdam, NL.

Silva S.R., da Silva I.R., de Barros N.F., and Mendonca E.D., 2011. Effect of compaction on microbial activity and carbon and nitrogen transformations in two Oxisols with different mineralogy. Revista Brasileira De Ciencia Do Solo, 35, 1141-1149.

Six J. and Paustian K., 2014. Aggregate-associated soil organic matter as an ecosystem property and a measurement tool. Soil Biol. Biochem., 68, A4-A9.
Tang J.W., Baldocchi D.D., Qi Y., and Xu L.K., 2003. Assessing soil $\mathrm{CO}_{2}$ efflux using continuous measurements of $\mathrm{CO}_{2}$ profiles in soils with small solid-state sensors. Agric. For. Meteorol., 118, 207-220.

Tenesaca C.G. and Al-Kaisi M.M., 2015. In-field management of corn cob and residue mix: Effect on soil greenhouse gas emissions. Appl. Soil Ecol., 89, 59-68.

Wolf B., Chen W.W., Brueggemann N., Zheng X.H., Pumpanen J., and Butterbach-Bahl K., 2011. Applicability of the soil gradient method for estimating soil-atmosphere $\mathrm{CO}_{2}, \mathrm{CH} 4$, and $\mathrm{N}_{2} \mathrm{O}$ fluxes for steppe soils in Inner Mongolia. J. Plant Nutr. Soil Sc., 174, 359-372.

Zuber S.M., Behnke G.D., Nafziger E.D., and Villamil M.B., 2015. Crop rotation and tillage effects on soil physical and chemical properties in Illinois. Agronomy J., 107, 971-978. 